\title{
Bauran Pemasaran Dalam Meningkatkan Penjualan Produk Pada Pondok Jamur Zidan Palangka Raya
}

\author{
Almaysa Widya Krisma ${ }^{1 *}$, Kuwing Baboe ${ }^{2}$, Sundari ${ }^{3}$, Eko Riadi ${ }^{4}$ \\ 1,2.3,4Program Studi Pendidikan Ekonomi, FKIP, Universitas Palangka Raya \\ *Corres pondence author: almaysawidya19@gmail.com; Tel.: +62822189876XX
}

\begin{abstract}
Marketing Mix is a mixture of various el ements which includes products, prices, places and promotions carried out by companies aimed at ma rketing products or services effectively and satisfying / fulfillingconsumer needs. The purpose of this study is to describe and determine the process of making plantingmedia on mushrooms at Zidan Mushroom Pondok Palangka Raya and the Marketing Mix at Zidan Palangka Raya Mus hroomCottagein Increasing Product Sales. The method used in this res earch is descriptive-quali tativemethod,namelytheresearcher is intended to collect data or information about an existing phenomenon. The types of data used areprimarydata and secondary data. Data coll ection techniques consisting of obs ervation, interviews and documentation.Data analysis was us ed by using techniques from three stages of activiti es carried outsequentially,namelyreducingdata, pres enting data, and drawing conclusions. The results showed that in carrying outmarketingactivitiesinincreasing product sales at Pondok Mushroom Zidan Palangka Raya, we must pay attention to a cti vities intheelements of the marketing mix, namely product, price, place / distribution channel a nd promotion. Thereareseveral obstacles that affect marketing activities in increasing product sales at Zidan Mushroom PondokPalangka Raya,especiallythelack of labor and less strategic production sites. Based on the results of Fishbone's a nalysis of theZidanPalangka Raya Mushroom Cottage marketing mix, a solution to the problems that occurred was found, Zidan Palanga Raya Mus hroom Cottage can a dd or recruit empl oyees so that production and sales increase, and see a less strategic business location, in this case so that business owners can pay attention to the place ofbusiness sothatcustomers or consumers are easy to reach the business location.
\end{abstract}

Keyword: Marketing Mix, Product

Abstrak: Bauran Pemasaran merupakan merupakan campuran berbagai uns ur ya ngdidalamnya termasuk,produk, ha rga, tempat dan promosi yang dilakukan perusa haa n bertujuan untuk memasarkan produkataujasa secara efektif dan da pat memuaskan/memenuhi kebutuhan konsumen. Tuj uan peneli tian ini yaitu untuk men deskripsikandan mengetahui Proses pembuatan media tanam pada jamur Di Pondok Jamur Zidan Palangka Raya dan Bauran Pemasaran Pada Pondok Jamur Zidan Palangka Raya Dalam Meningkatkan Penjualan Produk. Metode yang digunakan dala m penelitian adalah metode des kriptif-kualita tif yaitu penel iti dimaksudkanuntukmengumpulkan da ta a ta u informasi mengenai suatu fenomena yang a da. Jenis da ta yang digunakan adalah dataprimerdandata sekunder. Teknik pengumpulan data yang terdiri dari observasi, wawancara dan dokumentasi. Analisis data digunakan dengan menggunakan teknik dari tiga taha pan kegia tan yang dilaksanakan secara berurutan yaitu mereduksi data, penyajian data, dan penarikan kesimpulan. Hasil penelitianmenunjukkanbahwa dalammelakukan kegiatan pemasaran dalam meningkatkan penjualan produk Pada Pondok Jamur Zidan Palangka Raya harus memperhatikan kegiatan dalam unsur bauran pemasaran yaitu produk, harga, tempat/saluran distribusi dan promosi. Terda pat beberapa kendala yang mempenga ruhi kegia tan pemasaran dala m meningkatkanpenjualan produk pada Pondok Ja mur Zi dan Palangka Raya, teruta ma kurangnya tenaga kerja dantempatproduksiyangkurang strategis. Berdasarkan hasil anal isis Fishbone terhadap bauran pemasaran Pondok Ja mur Zidan Palangka Raya ditemukan solusi dari permasala han yang terjadi, Pondok Jamur Zi danPalanga Raya dapatmenambahataumerekrut karyawan sehingga produksi maupun penjualan menja di meningkat, dan melihatlokasi usaha yangkurangstrategis, dalam hal ini agar pemilik usa ha dapat memperhatikan tempat usaha sehingga pelangganataukonsumenmudah untuk menjangkau lokasi usaha. 
Edunomics Journal, Vol. 2 (2): page 87-94, Juli 2021

Kata Kunci: Bauran Pemasaran, Produk

\section{Pendahuluan}

Usaha meningkatkan penjualan sangat berpengaruh terhadap volume penjualan perusahaan. Perusahaan yang tidak dapat memenuhi selera konsumen akan mengalami penurunan volume penjualan. Misalnya, dengan semakin banyaknya pesaing usaha maka persaingan dalam jenis industri yang sama sebaiknya mempunyai spesifikasi produk yang unggul. Disamping itu perusahaan harus mampu memahami kebutuhan konsumen, mendesain dan mengontrol kualitas pelayanan secara efektif. Menurut Thamrin Abdullah dan Francis Tantri (2012) Pemasaran adalah suatu sistem total dari kegiatan bisnis yang dirancang untuk merencanakan, menentukan harga, mempromosikan dan mendistribusikan barangbarang yang dapat memuaskan keinginan dan jasa baik kepada para konsumen saat ini maupun konsumen potensial. Kegiatan pemasaran suatu perusahaan memiliki beberapa tujuan yang hendak dicapai baik tujuan jangka pendek maupun tujuan jangka panjang. Dalam jangka pendek biasanya untuk merebut hati konsumen terutama untuk produk yang akan diluncurkan oleh perusahaan. Sedangkan dalam jangka panjang dilakukan untuk mempertahankan produk yang sudah ada agar tetap eksis dikalangan para konsumen. Menurut Fajar Laksana (2008:4) Pemasaran adalah aktivitas yang ditujukan untuk memenuhi kebutuhan dan keinginan konsumen melalui proses pertukaran. Strategi pemasaran mempunyai peranan penting untuk mencapai keberhasilan usaha, oleh karena itu bidang pemasaran berperan besar dalam merealisasikan rencana usaha. Pemasaran yang dilakukan perusahaan dapat menggunakan pola rencana dan taktik tertentu sehingga penjualan menjadi lebih tinggi. Dalam mencapai strategi pemasaran yang tepat untuk diterapkan, salah satunya perusahaan dapat melihat dari bauran pemasaran. Bauran pemasaran merupakan salah satu strategi yang dijalankan perusahaan, yang berkaitan dengan penentuan, bagaimana perusahaan menyajikan penawaran produk pada segmen pasar tertentu, yang merupakan sasaran pasarannya. Memahami strategi pemasaran adalah kemampuan untukmenjual atau mendistribusikan produk agar target perusahan dapat dicapai. Untuk keperluan tersebut perusahaan dapat melakukan tindakan-tindakan yang terdiri dari 4 macam, yaitu : tindakan mengenai Produk (product), Harga (price), tempat atau saluran distribusi (place), dan Promosi (promotion). Menurut Titik Wijayanti (2012) Bauran pemasaran merupakan hasil kolaborasi empat unsur, yang terdiri atas produk, harga, promosi dan distribusi. Setiap unsurnya mempunyai peran dan fungsi yang berbeda tetapi merupakan satu kesatuan yang tidak bisa terpisahkan satu sama lain. Oleh karena itu bauran marketing harus dibuat secara menyeluruh dan terarah dengan baik sesuai dengan strategi marketing yang terlah ditetapkan. Pondok Jamur Zidan Palangka Raya merupakan industri rumah tangga (home industry) di kota Palangka Raya yang bergerak dibidang budidaya jamur tiram, yang memproduksi yaitu jamur tiram segar, baglog jamur tiram, bibit jamur F2 dan juga limbah dari baglog jamur itu sendiri. Dimana usaha yang dijalankan merupakan olahan pada proses pembuatan media tanam yang disbeut baglog dan bibit jamur tiram yaitu dari serbuk kayu, dedak, kapur, jagung dan juga bahan-bahan pelengkap lain yang dibutuhkan. Bagian tersulit adalah membuat baglog, media tanam yang telah diinokulaikan dengan bibit jamur. Ada dua kegiatan utama dalam budidaya jamur tiram. Tahap pertama adalah membuat media tanam dan menginokulasikan bibit jamur ke dalam media tanam tersebut. Sehingga media ditumbuhi miselium berwarna putih seperti kapas. Tahap kedua adalah menumbuhkan miselium tersebut menjadi badan buah. Permasalahan yang muncul dalam memasarkan produk Pondok Jamur Zidan Palangka Raya yaitu tentang bauran pemasarannya dalam meningkatkan hasil penjualan produk dikarenakan adanya pesaing yang juga memasarkan dan memproduksi produk sejenis dengan produk di Pondok Jamur Zidan Palangka Raya.

\section{Metode}

Ditinjau dari jenis datanya pendekatan penelitian yang digunakan dalam penelitian ini adalah pendekatan kualitatif. Sugiyono (2007) menyatakan sebagai berikut: Metode penelitian kualitatif adalah 
Edunomics Journal, Vol. 2 (2): page 87-94, Juli 2021

metode penelitian yang digunakan untuk meneliti pada kondisi obyek yang alamiah, (sebagai lawannya adalah eksperimen) dimana peneliti adalah sebagai instrument kunci, teknik pengumpulan data dilakukan secara trianggulasi (gabungan), analisis data bersifat induktif, dan hasil penelitian kualitatif lebih menekankan makna dari pada generalisasi. Jenis penelitian yang digunakan dalam penelitian ini ialah deskriptif-kualitatif, yaitu peneliti dimaksudkan untuk mengumpulkan data atau informasi mengenai suatu fenomena yang ada. Menurut Sudarwan Danim (2013) Penelitian deskriptif dapat pula diartikan sebagai penelitian yang dimaksudkan untuk memotret fenomena individual, situasi, atau kelompok tertentu yang terjadi secara kekininian". Peneliti mengambil lokasi penelitian di Pondok Jamur Zidan Palangka Raya yang berada di Jln. Candra Buana II, RTA Milono KM 6, Langkai, Kec. Pahandut, Kota Palangka Raya, Provinsi Kalimantan Tengah. Data primer merupakan data yang diperoleh langsung oleh peneliti melalui sumber asli tidak melalui media perantara. Data yang diperoleh dari responden langsung yaitu kepada pemilik usaha Pondok Jamur Zidan Palangka Raya Bapak Nuryadin Ghofur dan karyawan Pondok Jamur Zidan Palangka Raya Bapak Dwi Hadi Wibowo. Data sekunder merupakan data yang diperoleh peneliti secara tidak langsung melalui media perantara yang berupa bukti catatan at au laporan historis dalam arsip baik yang dipublikasikan maupun tidak dipublikasikan. Data yang diperoleh penulis yaitu berupa data penjualan produk pada Pondok Jamur Zidan Palangka Raya. Teknik pengumpulan data yang peneliti gunakan adalah : Observasi, Wawancara, Dokumentasi.

\section{Analisis Data}

Dalam penelitian ini alat analisis data yang digunakan adalah sebagai berikut: 1) Reduksi data dilakukan secara terus menerus saat melakukam penelitian untuk menghasilkan catatan-catatan inti dari data yang dari hasil penggalian data. Mereduksi data berarti merangkum, memilih hal-hal yang pokok, memfokuskan pada hal-hal penting, dicari tema dan polanya. Dengan demikian data yang direduksi akan memberikan gambaran yang jelas, dan mempermudah untuk melakukan pengumpulan data selajutnya, dan mencarinya bila diperlukan. 2) Setelah data direduksi, maka selanjutnya adalah penyajian data. Dalam penelitian ini penyajian data dilakukan dengan uraian singkat. Penyajian data merupakan kegiatan sekumpulan informasi yang disusun, sehingga memberi kemungkinan akan adanya penarikan kesimpulan. Penyajian data kualitatif dilakukan dalam bentuk tabel, grafik, pictogram dan sebagainya. Melalui penyajian data tersebut, maka data terorganisasikan, tersusun dalam pola hubungan, sehingga akan semakin mudah di pahami. 3) Langkah ketiga dalam analisis data pada penelitian ini adalah penarikan kesimpulan dan verifikasi. Dari data-data informasi yang sudah dikumpulkan melalui observasi, wawancara dan dokumentasi sehingga diperoleh permasalahan yang muncul. Penarikan kesimpulan merupakan salah satu analisis data kualitatif. Penarikan kesimpulan adalah hasil analisis yang dapat digunakan untuk mengambil tindakan. Kesimpulan harus diverifikasi karena dari verifikasi dapat dilakukan untuk mencari pembenaran dan persetujuan sehingga validitasnya tercapai. 


\section{HASIL DAN PEMBAHAASAN Hasil Penelitian}

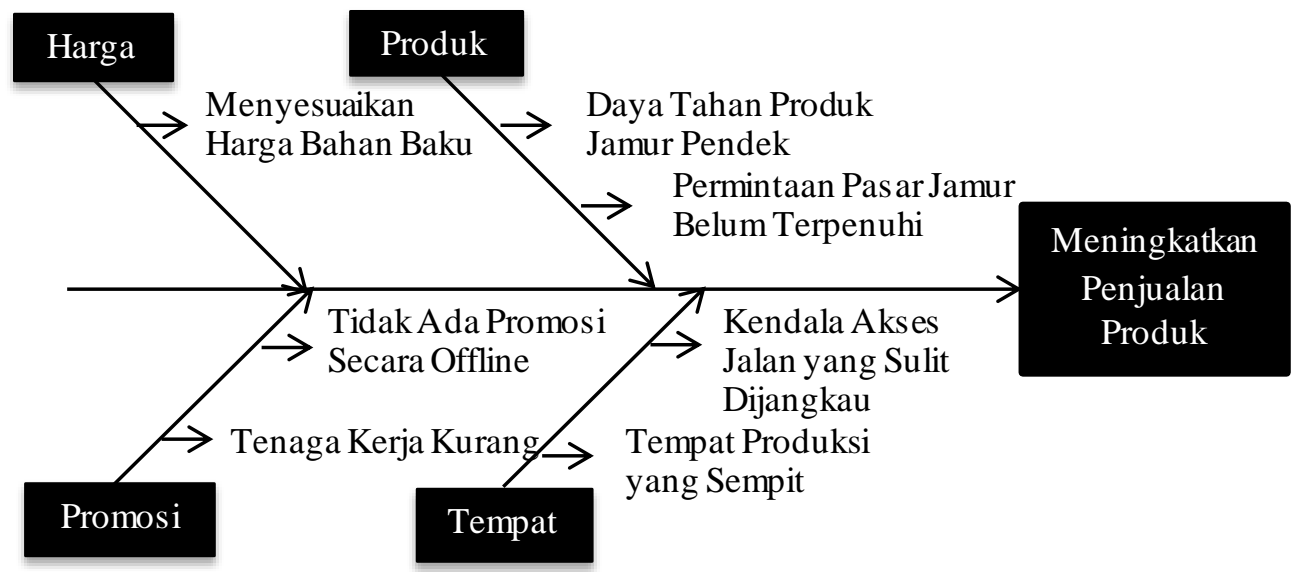

Sumber: Data Diolah

Gambar 1. Diagram Fishbone Pondok Jamur Zidan Palangka Raya

Tabel 1. Hasil Penemuan Permasalahan Sebab-Akibat

\begin{tabular}{|c|c|}
\hline Faktor Yang Diamati & Masalah Yang Terjadi \\
\hline - Produk & $\begin{array}{ll}\text { - } & \text { Daya tahan jamur pendek } \\
\text { - } & \text { Permintaan pasar produk jamur } \\
& \text { belum terpenuhi }\end{array}$ \\
\hline - Harga & Menyesuaikan harga bahan baku \\
\hline - Tempat & $\begin{array}{ll}\text { - } & \text { Akses jalan sulit } \\
\text { - } & \text { Tempat produk sempit/kurang } \\
& \text { strategis }\end{array}$ \\
\hline - Promosi & $\begin{array}{ll}\text { - } & \text { Tidak ada promosi secara offline } \\
\text { - } & \text { Tenaga kerja kurang } \\
\end{array}$ \\
\hline
\end{tabular}

Berdasarkan hasil wawancara penelitian mengenai bauran pemasaran yang ditetapkan oleh Pondok Jamur Zidan Palangka Raya sudah menerapkan keempat variabel bauran pemasaran yaitu produk, harga, tempat/saluran distribusi, dan promosi yang sesuai dengan teori dari satu pendapat ahli. Namun pada saat penerapan keempat unsur bauran pemasaran ada beberapa kendala yang dihadapi oleh Pondok Jamur Zidan Palangka Raya. Pertama pada produk yaitu jamur tiram sendiri yang memilik daya tahan pendek sehingga pada saat jamur tiram sudah dipanen maka harus segera habis terjual dan permintaan pelanggan pada produk jamur tiram yang belum terpenuhi karena tergantung dari persediaan media tanam baglog yang tersedia, maka berpengaruh pada hasil produksi jamur tiram. Kedua harga pada produk Pondok Jamur Zidan Palangka Raya yang mengikuti harga bahan baku, namun pada saat harga bahan baku naik tidak secara langsung Pondok Jamur Zidan Palangka Raya menaikkan harga, karena di Palangka Raya memiliki sebuah komunitas petani jamur maka ketika akan menaikkan harga produk yang akan dijual perlu di bicarakan dengan para petani jamur lainnya. Ketiga dalam hal tempat disini yang dimaksud tempat usaha atau produksi yang masih belum strategis karena akses ke tempat usaha yang masih sulit dijangkau oleh pelanggan atau konsumen dan lokasi yang sempit serta mudah terkena banjir. 
Berdasarkan hasil penelitian dan wawancara, pemilik usaha hanya menetapkan media pemasaran yang digunakan melalui media pemasaran secara online, menggunakan promosi melalui aplikasi WhatssApp, Facebook, dan Instagram. Pemilik berpendapat bahwa melalui pemasaran online lebih mudah menyaring para pelanggan atau konsumen sehingga mereka tertarik untuk langsung datang ke tempat usaha Pondok Jamur Zidan Palangka Raya. Dalam hal memproduksi produk dikarenakan keterbatasan tenaga kerja yang kurang hanya satu orang khusus untuk memproduksi baglog dan bibit F2 serta satu orang khusus untuk panen produk jamur tiram segar.

Tabel 2. Solusi dari Masalah yang Terjadi

\begin{tabular}{lll}
\hline Faktor yang Diamati & Solusi dari Masalah yang Terjadi \\
\hline - & - & Menambah kumbung/rumah \\
& budidaya jamur \\
& - & Memberikan batasan dalam \\
& & pembelian baglog \\
& - & Meningkatkan kualitas \\
& & pengemasan pada jamur \\
& - & Membuat pengembangan produk \\
- Harga & - & \\
- Tempat & - & Memasang plang nama/spanduk \\
& & usaha di pinggir jalan atau gang. \\
- Promosi & - & Membuat brosur/selebaran \\
& - & Menambah tenaga kerja \\
\hline
\end{tabular}

Berdasarkan data diatas pada permintaan pasar pada produk jamur tiram Pondok Jamur Zidan Palangka Raya dapat memberikan batasan dalam pembelian baglog sehingga volume jamur seimbang dengan permintaan baglog, membuat kumbung/rumah jamur khusus untuk produksi jamur tiram atau memanfaatkan kumbung yang sudah ada namun tidak dipergunakan sehingga dapat menghemat biaya, agar pada saat ada permintaan pada produk baglog jamur tidak mengambil dari stok khusus untuk jamur tiram. Sehingga produksi jamur tiram dapat dipertahankan, serta meningkatkan kualitas pengemasan pada jamur, dan ketika ada permintaan dari luar daerah pemilik mampu memenuhi permintaan tersebut sehingga pemasaran produk jamur menjadi luas dan dapat meningkatkan penjualan. Membuat atau memproduksi jamur tiram jenis yang la in sehingga pelanggan atau konsumen memiliki pilihan mengenai varian jamur tiram contohnya seperti jamur tiram cokelat, jamur tiram kuning, jamur tiram jenis Djamor (jamur tiram ungu), jamur tiram Pulmonarius (jamur tiram putih keabu-abuan) dan lain sebagainya. Pada tempat atau lokasi usaha yang masih sulit dijangkau pemilik usaha dapat memasang plang nama/spanduk di pinggir jalan atau gang sehingga pada saat konsumen/pelanggan ingin datang langsung ke lokasi mudah untuk mencari lokasi usaha Pondok Jamur Zidan Palanga Raya. Pada kegiatan Promosi dapat dilakukan secara offline dengan cara membuat brosur atau selebaran dengan penjelasan mengenai sistem penjualan yaitu pemilik memberikan bonus kepada pelanggan agar menarik minat pelanggan atau konsumen untuk membeli produk, serta usaha budidaya jamur tiram sehingga dapat membantu menjaring para pelanggan yang tidak dapat menjangkau menggunakan media online, sehingga adanya keseimbangan dalam memasarkan produk baik itu melalui media online dan media offline dan terus gencar melakukan promosi.

Berdasarkan hasil pengamatan bahwa pada bagian promosi secara online, kemudian pada saat melakukan pengantaran produk kepada pelanggan didalam kota Palangka Raya dilakukan oleh pemilik usaha sehingga yang merangkap sekaligus pada bagian promosi, pengantaran produk ke pelanggan, dan membuat laporan keuangan serta satu orang karyawan yang melakukan kegiatan produksi yang juga 
Edunomics Journal, Vol. 2 (2): page 87-94, Juli 2021

melaksanakan pekerjaan dalam mengantarkan produk, maka dari itu diperlukan adanya tenaga kerja tambahan agar dapat membagi tugas tersebut.

\section{Pembahasan Penelitian}

\section{Bauran Pemasaran Pondok Jamur Zidan Palangka Raya}

1) Produk

Produk yang dijual oleh Pondok jamur Zidan Palangka Raya terdapat 4 jenis produk yang ditawarkan kepada konsumen atau pelanggan yaitu, baglog/media tanam, jamur tiram segar, bibit $F 2$ dan limbah baglog, dalam mengolah produk Pondok Jamur Zidan Palangka Raya memiliki satu orang karyawan khusus yang membuat dan mengolah produk. Pada target pasar tidak membatasi siapa saja yang ingin membeli, mendapatkan atau mengkonsumsi produk Pada Pondok Jamur Zidan Palangka Raya maka dari itu produk yang dijual atau ditawarkan bisa di minati/dimiliki oleh kalangan masyarakat. Setiap produk memiliki kelebihan dan kelemahannya masing-masing, terutama pada produk baglog dan jamur tiram. Kelebihan yang di miliki produk baglog pada Pondok Jamur Zidan Palangka Raya yaitu lebih konsisten tumbuh jamurnya dimana pemilik usaha selalu menjaga komposisi bahan baku dari awal pembuatan baglog, kelemahan baglog tergantung pada saat ada bahan baku yang jelek sehingga mengakibatkan penurunan kemampuan tumbuh jamur tiram. Pada produk jamur Pondok Jamur Zidan Palangka Raya memiliki cara packing atau kemasan yang berbeda dengan para penjual jamur yang lain yaitu dengan cara di sealer agar udara tidak masuk karena kelemahan dari produk jamur yang memiliki daya tahan yang pendek. Pada produk bibit F2, para petani jamur di Palangka Raya lebih banyak membeli di Pondok Jamur Zidan karena adaptasi bibit ke baglog yang cepat, yang berarti produk bibit F2 yang dimiliki oleh Pondok Jamur Zidan Palangka Raya memiliki kualitas yang bagus. Ada beberapa produk andalan yang dimiliki oleh Pondok Jamur Zidan Palangka Raya yaitu pada produk baglog/media tanam dan jamur tiram segar sendiri dimana peminat lebih banyak membeli kedua produk tersebut. Dalam pengembangan produk di Pondok Jamur Zidan Palangka Raya sementara masih tetap bertahan. Permintaan pasar belum terpenuhi, terutama pada produk jamur tiram segar, karena banyak pelanggan/konsumen yang membeli baglog otomatis persediaan baglog berkurang mengakibatkan volume jamur tiram menjadi berkurang. Pada produk baglog bersifat fluktuatif, sedangkan pada bibit F2 mengalami kenaikan permintaan dari luar daerah. Dalam mempertahankan kualitas, pertama Pondok Jamur Zidan selalu menjaga komposisi pada bahan baku pembuatan baglog maupun pada bibit F2, kedua selalu menjaga ketersediaan produk agar ketika pembeli atau pelanggan membeli kersediaan produk selalu ada, apabila persediaan kurang atau tidak dapat memenuhi permintaan konsumen pemilik berusaha selalu bersikap jujur kepada pelanggan dalam menyampaikan persediaan yang ada maupun tidak ada. Ketiga pemilik memberikan layanan after sales atau layanan setelah penjualan, ketika pembeli mengalami keluhan ata u terdapat masalah pada produk yang diterima pemilik menerima keluhan dan mencoba untuk mencari solusi dari masalah tersebut.

2) Harga

Dalam mematok harga produk berdasarkan yang pertama mengikuti harga pasaran dengan para petani jamur tiram yang lain. Kedua berdasarkan harga bahan baku. Bahan baku yang diperoleh Pondok jamur Zidan Palangka Raya didapatkan langsung dari supplier sehingga harga bahan baku dapat lebih murah. Terdapat salah satu faktor yang mempengaruhi harga terutama pada produk baglog, secara pribadi pemilik usaha tidak dapat semerta-merta menaikkan harga produk ketika harga bahan baku naik. Harga produk yang dijual oleh Pondok Jamur Zidan Palangka Raya sama dengan para petani jamur lainnya pada harga produk baglog Rp. 5.000/unit, Perbedaan terletak pada harga jamur yang berkisar Rp. 25.000 sampai Rp. 30.000, dan harga bibit F2 Rp. 12.000 sampai Rp. 13.000. Dalam meningkatkan penjualan pemilik Pondok Jamur Zidan Palangka Raya menerapkan sistem bonus kepada pelanggan atau/konsumen yang membeli produk, pada produk baglog jika pembeliaan 1.000 pcs maupun diatas 1.000 pcs maka akan diberikan bonus 50 pcs produk baglog. Pada bibit F2 apabila pembelian di atas 10 pcs maka harga jual menjadi Rp. 12.000 serta pembelian kelipatan 10 akan mendapat bonus 1 produk sehingga tidak 
menurunkan harga jual produk. Karena sifatnya bonus, apabila kekurangan stok tidak memberikan bonus tidak terjadi masalah berbeda apabila memberikan potongan harga. Sistem pembayaran yang dilakukan antara pemilik (penjual) dengan pembeli (konsumen/pelanggan) yaitu transaksi pembayaran langsung ditempat pembelian dan melalui via transfer.

3) Tempat

Pemilik menyalurkan produk secara langsung ke pelanggan. Apabila ada permintaan dari luar kota Palanga Raya pemilik menggunakan jasa kurir/jasa angkut pick up. Penyaluran produk sudah sampai ke kabupaten-kabupaten yang ada di Kalimantan Tengah terkhusus untuk produk Baglog dan Bibit F2 yaitu ke kabupaten Kotawaringin Timur, Seruyan, Tumbang Samba, Buntok, sementara untuk produk jamur tiram masih disalurkan didalam kota Palangka Raya belum sampai keluar kota. Jalur distribusi menggunakan jalur darat yaitu menggunakan kendaraan pribadi ataupun menggunakan jasa kurir/angkutan untuk mengirim barang ke konsumen. Alat produksi dalam memproduksi menggunakan Isitrik apabila ada pemadaman listrik maka alat tidak dapat digunakan maka dari itu pemilik menggunakan genset untuk menyelesaikan permasalahan tersebut. Tempat produksi Pondok Jamur Zidan Palanga Raya saat ini belum bisa dikatakan strategis, terkendala aksesjalan yang dilewati dan juga mudah banjir a pabila musim penghujan.

4) Promosi

Dalam mempromosikan produk lebih menggunakan media online seperti WhatsApp (WA), facebook (FB) dan memiliki akun Instagram (@ pondok_jamur_zidan) khusus PondokJamur Zidan Palangka Raya dan belum ada promosi secara offline, offline apabila pembeli langsung datang ke tempat usaha. Promosi dilakukan dengan cara update story maupun posting foto dan video untuk memasarkan produk pada akun media sosial yang telah ada. Pondok jamur Zidan Palangka Raya tidak merasakan adanya kendala dalam melalukan promosi secara online, dengan media online lebih mudah untuk menjaring para konsumen secara luas dan tidak menggunakan biaya yang besar, pemilik juga merasakan pengaruhnya promosi terhadap penjualan produk dan wajib promosi produk secara terus-menerus. Dalam meningkatkan penjualan, pembelian kelipatan 10 akan mendapat bonus 1 produk sehingga tidak menurunkan harga jual produk. Karena sifatnya bonus, apabila kekurangan stok tidak memberikan bonus tidak terjadi masalah berbeda apabila memberikan potongan harga.

\section{Kesimpulan}

Berdasarkan hasil penelitian dan pembahasan, dapat disimpulkan sebagai berikut: 1) Strategi pemasaran yang tepat untuk meningkatkan penjualan produk ialah dengan menerapkan 4 unsur dalam bauran pemasaran diantaranya, produk, harga, tempat/saluran distribusi, dan promosi, serta menerapkan strategi pemasaran langsung dan tidak langsung dengan prioritas pada produk dan harga yang dipasarkan. 2) Bauran pemasaran pada Pondok Jamur Zidan Palangka Raya telah menerapkan keempat unsur dari bauran pemasaran, namun ada beberapa kendala yang mempengaruhi dalam meningkatkan penjualan produk yaitu kurangnya tenaga kerja dalam memproduksi produk dan tempat produksi yang kurang strategis. 3) Berdasarkan analisis Fishbone pada Pondok Jamur Zidan Palangka Raya maka dapat disimpulkan bahwa: terdapat beberapa masalah yang mempengaruhi bauran pemasaran dalam meningkatkan penjualan produk yaitu, daya tahan produk jamur tiram yang pendek, permintaan pasar yang belum terpenuhi terhadap produk jamur sendiri, harga jual menyesuaikan terhadap harga bahan baku, promosi produk yang hanya fokus pada media online, tenaga kerja dalam memproduksi produk kurang, serta tempat produksi yang kurang strategis. 


\section{Daftar Pustaka}

Andrew Kurniawan Vadreas. 2016. Aplikasi E-Commerce Dengan Metode Fishbone Analysis Pada Usaha Dagang Hasil Laut Di Sikakap Kabupaten Kepulauan Mentawai Menuju Masyarakat Ekonomi Asean (Mea). Jurnal Momentum Vol. 18 No 2:14, dari: https://garuda.ristekbrin.go.id/documents/detail/1452595.

Dadang A. K., Evita S. H., \& Julian A. R. 2018. Analisis Efisiensi Pemasaran Baglog Dan Jamur Tiram Putih Pada UD Aroma Jamur Di Kabupaten Lumajang. JSEP Vol 11 No. 1: 20-21, dari: https://jurnal.unej.ac.id/index.php/JSEP/article/view/5832.

Danim, Sudarwan. 2013. Menjadi Peneliti Kualitatif. Bandung: CV Pustaka Setia.

Djunita Permata Indah. 2020. Analisis Fishbone Diagram Untuk Mengevaluasi Proses Bisnis Distribusi Air Pada PDAM Studi Kasus Pada PDAM Tirta Raya Kabupaten Kubu Raya. Jurnal Akuntansi Vol. 6 No 1:1-16, dari: https://financial.ac.id/index.php/financial/article/view/130/pdf.

Hurriyanti, Ratih. 2005. Bauran Pemasaran \& Loyalitas Konsumen. Bandung: Alfabeta.

Hariatama, Fendy. 2021. Analisis SWOT Terhadap Pelaksanaan Bauran Pemasaran (Marketing Mix) Pada Lembaga Pendidikan Prima Mandiri Utama Palangka Raya. Edunomics Journal 2 (1), 1-12.

Indrawan, Rully dan Yaniwati, Poppy. 2016. Metodologi Penelitian: Kuantitaif, Kualitatif, dan Campuran untuk Manajemen, Pembangunan dan Pendidikan. Cetakan ke Dua. Bandung: PT Refika Aditama.

Jennifer, Alexandra. 2019. Fishbone Analysis. Diunduh pada tanggal 20 Januari 2021 dari https://sis.binus.ac.id/2019/07/19/fishbone-analysis/.

Laksana, Fajar. 2008. Manajemen Pemasaran. Yogyakarta. Graha Ilmu.

MEILINDA, Rima. 2020. Analisis SWOT Marketing MIX Pada SMA Muhammadiyah 1 Palangka Raya. Edunomics Journal, Vol. 1 (1): page 8-13, July 2020.

Okciana, Sari. 2018. Strategi Pemasaran Pada Grage Rotan Palangka Raya. Skripsi S1. Universitas Palangka Raya.

Sofjan, Assauri. 2014. Manajemen Pemasaran: Dasar, Konsep, dan Strategi, cetakan ke-13. Jakarta: PT Raja Grafindo.

Sugiyono. 2010. Metode Penelitian Pendelatan Kuantitatif, Kualitatif, dan R\&D. Bandung: Alfabeta.

Thamrin, Abdullah dan Francis, Tantri. 2012. Manajemen Pemasaran. Jakarta: Grafindo Persada

Titik, Wijayanti. (2008). Marketing Plan! Perlukah?. Jakarta: PT Elex Media Komputindo.

Sidrotul, Muntaha. 2018. Lingkungan Pemasaran. Diunduh pada tanggal 12, Oktober 2020 dari https://www.alihamdan.id/lingkungan-pemasaran/.

Violin F. S, \& Regia I. K. S. 2016. Bauran Pemasaran Pada Usahatani Jamur Tiram Putih Di P4s Nusa Indah Kabupaten Bogor. Jurnal Agrimart Vol. 03 No. 1:8-9, dari:

https://docplayer.info/54956797-Bauran-pemasaran-pada-usahatani-jamur-tiram-putih-di-p4snusa-indah-kabupaten-bogor.html. 